\title{
GTS-21, an a7nAChR agonist, increases pulmonary bacterial clearance in mice by restoring hyperoxia-compromised macrophage function
}

Ravikumar A. Sitapara', Alex G. Gauthier, Vivek S. Patel', Mosi Lin', Michelle Zurr ${ }^{1}$, Charles R. Ashby Jr. ${ }^{1}$ and Lin L. Mantell $12^{1 *}$ (1)

\begin{abstract}
Background: Mechanical ventilation, in combination with supraphysiological concentrations of oxygen (i.e., hyperoxia), is routinely used to treat patients with respiratory distress, such as COVID-19. However, prolonged exposure to hyperoxia compromises the clearance of invading pathogens by impairing macrophage phagocytosis. Previously, we have shown that the exposure of mice to hyperoxia induces the release of the nuclear protein high mobility group box-1 (HMGB1) into the pulmonary airways. Furthermore, extracellular HMGB1 impairs macrophage phagocytosis and increases the mortality of mice infected with Pseudomonas aeruginosa (PA). The aim of this study was to determine whether GTS-21 (3-(2,4-dimethoxybenzylidene) anabaseine), an a7 nicotinic acetylcholine receptor (a7nAChR) agonist, could (1) inhibit hyperoxia-induced HMGB1 release into the airways; (2) enhance macrophage phagocytosis and (3) increase bacterial clearance from the lungs in a mouse model of ventilator-associated pneumonia.
\end{abstract}

Method: GTS-21 $(0.04,0.4$, and $4 \mathrm{mg} / \mathrm{kg})$ or saline were administered by intraperitoneal injection to mice that were exposed to hyperoxia $\left(\geq 99 \% \mathrm{O}_{2}\right.$ ) and subsequently challenged with PA.

Results: The systemic administration of $4 \mathrm{mg} / \mathrm{kg}$ i.p. of GTS-21 significantly increased bacterial clearance, decreased acute lung injury and decreased accumulation of airway HMGB1 compared to the saline control. To determine the mechanism of action of GTS-21, RAW 264.7 cells, a macrophage-like cell line, were incubated with different concentrations of GTS-21 in the presence of $95 \% \mathrm{O}_{2}$. The phagocytic activity of macrophages was significantly increased by GTS-21 in a dose-dependent manner. In addition, GTS-21 significantly inhibited the cytoplasmic translocation and release of HMGB1 from RAW 264.7 cells and attenuated hyperoxia-induced NF-KB activation in macrophages and mouse lungs exposed to hyperoxia and infected with PA.

Conclusions: Our results indicate that GTS-21 is efficacious in improving bacterial clearance and reducing acute lung injury via enhancing macrophage function by inhibiting the release of nuclear HMGB1. Therefore, the a7nAChR represents a possible pharmacological target to improve the clinical outcome of patients on ventilators by augmenting host defense against bacterial infections.

\footnotetext{
*Correspondence: mantelll@stjohns.edu; Imantell@northwell.edu

1 Department of Pharmaceutical Sciences, St. John's University College

of Pharmacy and Health Sciences, 8000 Utopia Parkway, Queens, NY

11439, USA

Full list of author information is available at the end of the article
} 
Keywords: a7nAChR, Hyperoxia, Macrophage function, HMGB1, NF-kB, Acute lung injury, Pulmonary infection

\section{Introduction}

Oxygen therapy, using mechanical ventilation (MV) with supraphysiological concentrations of oxygen (hyperoxia), is a lifesaving intervention for patients with respiratory distress (Ruggiu et al. 2018). However, patients on ventilators become highly susceptible to lung infections and have a greater likelihood of developing ventilator-associated pneumonia (VAP). Pseudomonas aeruginosa (PA), a gram-negative aerobic bacterium, has been reported to be associated with $21 \%$ of all VAP cases (Liu et al. 2008; Richards et al. 1999). VAP accounts for up to $60 \%$ of all deaths from hospital-acquired infections in the United States and continues to be a major cause of morbidity and mortality in patients on ventilators (Tablan et al. 2003; Ramirez Barba et al. 2006; Davis 2006).

Alveolar macrophages (AMs) are the first-line of defense against invading pathogens and are the earliest effectors of the phagocytic response against microbial infections in the distal airways (Aberdein et al. 2013; Franke-Ullmann et al. 1996). AMs isolated from animals and cultured macrophages exposed to hyperoxia have impaired phagocytosis of pathogens such as PA and Klebsiella pneumoniae, as well as paraffin oil droplets (Morrow et al. 2007; Patel et al. 2013; O’Reilly et al. 2003; Baleeiro et al. 2003; Rister 1982; Raffin et al. 1980; Crowell et al. 1995). Impaired macrophage functions have been correlated with increased susceptibility and severity of bacterial infections in animals exposed to hyperoxia (Patel et al. 2013; Baleeiro et al. 2003). However, macrophage bacterial clearance functions impaired by hyperoxia can be attenuated by compounds that enhance antioxidant capacity (Patel et al. 2016, 2020), donate exogenous nitric oxide (Gore et al. 2020), or inhibit NF-KB activation (Wang et al. 2015). The resulting enhanced macrophage functions can mitigate hyperoxia-induced excessive pro-inflammatory response in the lungs of mice and decrease acute lung injury (Patel et al. 2016; Entezari et al. 2014; Sitapara et al. 2020).

Prolonged exposure to hyperoxia also induces the accumulation of high mobility group box-1 protein (HMGB1) in the airways of mice and in the media of cultured macrophages (Patel et al. 2013, 2020; Entezari et al. 2012, 2014). High levels of airway HMGB1 have been reported in patients with cystic fibrosis and in patients on ventilators (Entezari et al. 2012; van Zoelen et al. 2008). Extracellular HMGB1 in the airways is sufficient to impair the phagocytic function of AMs (Entezari et al. 2012). Furthermore, HMGB1-compromised macrophage functions can result in decreased host defenses against bacterial infection in animal models of cystic fibrosis and VAP (Patel et al. 2013; Entezari et al. 2012). Thus, decreasing the accumulation of HMGB1 in the airways of patients with CF and VAP may provide an important therapeutic strategy for these patients.

Numerous studies have been directed towards elucidating the mechanisms underlying the release of nuclear HMGB1 into the extracellular milieu in order to develop treatments or interventions that attenuate the adverse effects of extracellular HMGB1 (Yang 2005; Wang 1999). The release of HMGB1 can be partly controlled by the cholinergic anti-inflammatory reflex (Andersson and Tracey 2011; Kang et al. 2014; Wang et al. 2019). This anti-inflammatory reflex relays the presence of inflammation, danger, and pathogen-associated molecular pattern signals via the afferent vagus nerve to the central nervous system for integration (Andersson and Tracey 2011; Kang et al. 2014; Wang et al. 2019). As a result, efferent vagus nerves are activated and stimulate the release of acetylcholine from effector cells, which activates the $\alpha 7$ nicotinic acetylcholine receptors $(\alpha 7 \mathrm{nAChR})$ on cells such as macrophages to decrease the production and secretion of pro-inflammatory cytokines (Andersson and Tracey 2011; Kang et al. 2014; Wang et al. 2019). Indeed, $\alpha 7 \mathrm{nAChR}$ activation plays a critical role in inhibiting the release of nuclear HMGB1 into the extracellular milieu (Wang et al. 2019; Ulloa 2005; Wang et al. 2004).

Macrophages express high levels of $\alpha 7 \mathrm{nAChR}$, which may be a target for decreasing the accumulation of extracellular HMGB1 (Wang et al. 2003; Khan et al. 2012 ). Indeed, $\alpha 7 n A C h R$ activation plays a critical role in inhibiting LPS-induced release of nuclear HMGB1 into the extracellular milieu (Wang et al. 2019; Ulloa 2005; Wang et al. 2004). GTS-21, 3-(2,4-dimethoxybenzylidene) anabaseine, is an agonist of $\alpha 7 \mathrm{nAChR}$ (Pavlov et al. 2007; Giebelen et al. 2007). GTS-21 has been shown to decrease the extracellular accumulation of HMGB1 in LPS-stimulated AMs (Wang et al. 2019). Furthermore, in a mouse model of LPS-induced acute lung injury, GTS21 decreased the (1) release of HMGB1 into the airways and serum and (2) HMGB1 mRNA expression (Wang et al. 2019). In order for nuclear HMGB1 to be actively released into the serum or the airways, it first needs to be translocated from the nucleus into the cytoplasm, which is associated with the activation of NF- $\mathrm{kB}$ (Wang et al. 2015; Kang et al. 2014; Wang et al. 2019). HMGB1 release and its extracellular accumulation from cultured macrophages after prolonged exposure to hyperoxia is accompanied by the activation of NF- $\mathrm{kB}$ (Wang et al. 
2015). By decreasing hyperoxia-induced activation of NF- $k B$, NF- $k B$ inhibitors can inhibit both hyperoxiainduced-HMGB1 releases from macrophages and macrophage dysfunction (Wang et al. 2015). Thus, the aim of this study was to determine the effects of GTS-21 on (1) hyperoxia-reduced host defense to clear PA infection in a mouse model of VAP, (2) hyperoxia-induced suppression of macrophage phagocytosis, and (3) the accumulation of extracellular HMGB1 in the airways of animals subjected to prolonged exposure to hyperoxia and PA lung infection.

\section{Materials and methods}

\section{Cell culture and reagents}

Murine macrophage-like RAW 264.7 cells (American Type Culture Collection-TIB-71, Manassas, VA) were cultured in RPMI 1640 medium (GIBCO/BRL Life Technologies Inc., Grand Island, NY) supplemented with $10 \%$ fetal bovine serum (Atlanta Biologicals, Lawrenceville, GA), $1 \%$ penicillin and $1 \%$ streptomycin (Life Technologies, Grand Island, NY). The cells were maintained at $37{ }^{\circ} \mathrm{C}$ under $\left(5 \% \mathrm{CO}_{2} / 21 \% \mathrm{O}_{2}\right)$ normoxic condition for $24 \mathrm{~h}$ and allowed to grow to $70-80 \%$ confluency and were subcultured every three days. GTS-21, 3-(2,4-dimethoxybenzylidene)-anabaseine dihydrochloride, was obtained from Abcam (Cambridge, MA).

\section{Bronchoalveolar lavage}

Murine bronchoalveolar lavage (BAL) fluid was obtained as described previously (Patel et al. 2013). Briefly, mice were anesthetized by an intraperitoneal injection of sodium pentobarbital $(120 \mathrm{mg} / \mathrm{kg})$. After a 1 - to $2-\mathrm{cm}$ incision was made on the neck, the trachea was dissected, and a 20 -gauge $\times 1.25$-inch intravenous catheter was inserted caudally into the lumen of the exposed trachea. The lungs were gently lavaged twice with $1 \mathrm{ml}$ sterile, nonpyrogenic PBS solution (Mediatech, Inc., Hendon, VA). The BAL samples were centrifuged, and the resultant supernatants were stored in a freezer at $-80{ }^{\circ} \mathrm{C}$ for analyzing concentrations of extracellular HMGB1 and the total protein content using Western blot analysis and a bicinchoninic acid assay, respectively.

\section{Animal studies}

C57BL/6 mice (male, 8-12-week-old; The Jackson Labs, Bar Harbor, ME) were used in this study in accordance with the Institutional Animal Care and Use Committee of St. John's University (Queens, NY). The mice were housed in a specific pathogen-free environment that was maintained at $22{ }^{\circ} \mathrm{C}$ in $\approx 50 \%$ relative humidity and with a $12 \mathrm{~h} \mathrm{light/dark} \mathrm{cycle.} \mathrm{All} \mathrm{mice} \mathrm{had} \mathrm{ad} \mathrm{libitum} \mathrm{access} \mathrm{to}$ standard rodent chow and water. Mice were randomized to receive either GTS-21 $(0.04,0.4$, and $4 \mathrm{mg} / \mathrm{kg})$ or saline, administered by intraperitoneal injection, every $8 \mathrm{~h}$, starting $32 \mathrm{~h}$ after the onset of hyperoxic exposure. After $48 \mathrm{~h}$ of exposure, the mice were inoculated with $0.1 \times 10^{8} \mathrm{CFU}$ of PA by making a 1 to $2 \mathrm{~cm}$ incision on the neck to expose the trachea following anesthetization with sodium pentobarbital $(60 \mathrm{mg} / \mathrm{kg})$. Eighteen hours after bacterial inoculation, mice were euthanized with intraperitoneal sodium pentobarbital $(120 \mathrm{mg} / \mathrm{kg})$ to obtain BAL and lung tissues as described previously (Patel et al. 2013). After lavaging with PBS, the lungs were excised and immediately placed into $1 \mathrm{ml}$ of cold PBS and homogenized.

\section{Exposure to hyperoxia}

Male C57BL/6 mice and cultured macrophages were exposed to hyperoxia as previously described (Patel et al. 2013). Briefly, animals were placed in micro-isolator cages (Allentown Caging Equipment Co., Inc., Allentown, NJ), which were kept in a Plexiglas chamber (BioSpherix, Lacona, NY) and exposed to $\geq 99 \% \mathrm{O}_{2}$ for up to $48 \mathrm{~h}$. The exposure of murine macrophage-like RAW 264.7 cells was done in sealed, humidified Plexiglas chambers (Billups-Rothenberg, Inc., Del Mar, CA), flushed with 95\% $\mathrm{O}_{2} / 5 \% \mathrm{CO}_{2}$ at $37{ }^{\circ} \mathrm{C}$. An oxygen analyzer (MSA; Medical Products, Pittsburgh, PA) was used to monitor the $\mathrm{O}_{2}$ concentration in the chamber.

\section{Western blot analysis}

To determine the levels of extracellular HMGB1, RAW 264.7 cells were cultured in serum-free Opti-MEM I medium (Gibco BRL, Grand Island, NY) in 12-well plates and were exposed to either $95 \% \mathrm{O}_{2}$ alone or $95 \% \mathrm{O}_{2}$ in presence of GTS-21 for $24 \mathrm{~h}$. After hyperoxic exposure, the levels of HMGB1 in the culture media of treated cells and BAL samples obtained from mice were measured by Western blot analysis. C57BL/6 mice were exposed to $\geq 99 \% \mathrm{O}_{2}$ for $48 \mathrm{~h}$, followed by inoculation with PA $\left(0.1 \times 10^{8} \mathrm{CFUs} / \mathrm{mouse}\right)$, and returned to their cages $(21 \%$ $\mathrm{O}_{2}$ ) after inoculation. Mice were randomized to receive either GTS-21 or saline, administrated by intraperitoneal injection, every $8 \mathrm{~h}$ starting at $32 \mathrm{~h}$ during hyperoxia. The levels of NF- $\mathrm{KB}$ and IкB in the nucleus and cytoplasm of lung cells in these mice were determined in nuclear and cytoplasmic extract prepared by using the NE-PER Nuclear and Cytoplasmic Extraction Reagents kit (Thermo Fisher Scientific, Waltham, MA), according to the manufacturer's protocol. Fifteen micrograms of nuclear extract, $30 \mu \mathrm{g}$ of cytoplasmic extract and an equal volume of BAL samples and culture media were loaded on to SDS-polyacrylamide gels (10\% and $13 \%)$ and then transferred to Immobilon-P membranes (Millipore, Bedford, MA, USA). Non-specific binding sites on the membrane were blocked using 5\% nonfat dry milk (Bio-Rad, 
Hercules, CA) in TBS (Tris-Buffered Saline) containing 1\% Tween 20 (TBST) for $1 \mathrm{~h}$ at room temperature. The membranes were rinsed three times with TBST and incubated overnight at $4{ }^{\circ} \mathrm{C}$ with rabbit anti-HMGB1 polyclonal primary antibody (1:500; Sigma Aldrich), anti-NF-kB p65 rabbit polyclonal antibody (1:500; Santa Cruz Biotechnology, Dallas, TX) and anti-IкB antibody (1:1000; Sigma Aldrich, St Louis, MO) diluted in 5\% nonfat dry milk. After three washes in TBST, the membranes were incubated with anti-rabbit horseradish peroxidescoupled secondary antibody (1:5000; GE Healthcare, Piscataway, NJ) for $1 \mathrm{~h}$ at room temperature. After washing the membranes thrice in TBST, the immunoreactive proteins were visualized using the enhanced chemiluminescence (ECL) reagent kit (Amersham Pharma Biotech, Piscataway, NJ) as per the manufacturer's instructions. The image was developed using a UVP Biospectrum 600 Imaging System (Vision Works LS, Upland, CA).

\section{Immunofluorescence analysis}

RAW 264.7 cells were seeded in 12-well plates and allowed to adhere overnight at $37{ }^{\circ} \mathrm{C}$. RAW 264.7 cells were exposed to either $95 \% \mathrm{O}_{2}$ alone or $95 \% \mathrm{O}_{2}$ in the presence of GTS-21 for $24 \mathrm{~h}$. After incubation for $24 \mathrm{~h}$, the cells were fixed with $2 \%$ phosphate-buffered formaldehyde ( $\mathrm{pH}$ 7.4) for $15 \mathrm{~min}$ and washed three times with PBS. Cells were then permeabilized with $0.2 \%$ Triton X-100 (Sigma-Aldrich, St Louis, MO) and nonspecific binding sites were blocked with $10 \%$ normal goat serum (NGS) (Chemicon, Temecula, CA) for 20 min. Next, cells were washed with $1 \%$ BSA in PBS and incubated with anti-HMGB1 (1:200, Sigma Aldrich, St Louis, MO) or NF-kB p65 (1:200, Santa Cruz Biotechnology, Dallas, TX) primary antibodies overnight at $4{ }^{\circ} \mathrm{C}$. The incubation with the secondary antibody, a goat anti-rabbit immunoglobulin G (IgG) conjugated with Alexa fluor 594 (1:200, Molecular Probes, Eugene, OR) was performed for $1 \mathrm{~h}$. Normal blocking serum without primary antibody was used as a negative control. To visualize the nuclei, cells were counterstained with DAPI (4',6-diamidino-2-phenylindole). HMGB1 and NF- $\mathrm{kB}$ translocation was observed under immunofluorescence microscope (Nikon, Melville, NY).

For quantifying the translocation for NF- $\mathrm{kB}$ or HMGB1 signals, fluorescent micrographs obtained from the above assays were subjected to Fiji ImageJ analysis (version 2.0) with the JACoP plugin, which was used to determine a Mander's Correlation Coefficient using regionof-interest thresholds to measure the magnitude of red signal (staining for NF- $\mathrm{kB}$ p65 or HMGB1) colocalizing with the DAPI (staining for the nucleus) signal. The calculated amount of signal colocalization was determined by using the Mander's Correlation Coefficient that was then represented as a relative amount of NF- $\mathrm{kB}$ p 65 colocalization with the nucleus or as a percent of HMGB1 located in the nucleus, normalized to the macrophages that remained in room air concentrations of oxygen.

\section{Phagocytosis assay}

The phagocytosis assay was performed as previously described, with minor modifications (Morrow et al. 2007). RAW 264.7 cells were seeded in 48 -well plates and were allowed to adhere overnight at $37{ }^{\circ} \mathrm{C}$. RAW 264.7 cells were exposed to either $95 \% \mathrm{O}_{2}$ alone or $95 \% \mathrm{O}_{2}$ in the presence of GTS-21 for $24 \mathrm{~h}$. After incubation, RAW 264.7 cells were kept at $37{ }^{\circ} \mathrm{C}$ in the presence of FITClabeled latex minibeads (Polysciences, Warrington, PA), at a ratio of 100:1 (beads/cell). Macrophages were washed with ice-cold PBS to stop phagocytosis, fixed with $4 \%$ paraformaldehyde for $10 \mathrm{~min}$ and washed with PBS. The fluorescence of the beads that were not phagocytosed by cells was quenched by incubating cells for $10 \mathrm{~min}$ with $0.4 \%$ trypan blue in PBS. The cytoskeleton was visualized by staining with Texas Red X-phalloidin (Molecular Probes, Eugene, OR) in 1\% BSA. Phagocytosis or the uptake of the latex beads was assessed using an immunofluorescence microscope (Nikon Inc, Melville, NY) by counting 250 consecutive individual macrophages/well in duplicates from three independent experiments for each treatment group. Fluorescent beads and cells were manually and blindly counted. The phagocytic activities were quantified using the number of beads per macrophage and presented as percent (\%) phagocytic activity compared to RA control group.

\section{Statistical analysis}

The data is presented as the mean \pm SEM of at least two independent experiments. The integrated area density of immunoreactive bands was measured using ImageJ Software and the data was analyzed using a Student's $t$ test using MS Excel software. A p-value of $<0.05$ was considered statistically significant.

\section{Results}

The systemic administration of GTS-21 significantly increases bacterial clearance and decreases acute lung injury in a mouse model of VAP

To determine if GTS-21 increases bacterial clearance under hyperoxic conditions, male C57BL/6 mice were exposed to $\geq 99 \% \mathrm{O}_{2}$ for $48 \mathrm{~h}$ as described previously (Patel et al. 2013) and given either GTS-21 (0.04, 0.4 and $4 \mathrm{mg} / \mathrm{kg}$ ) or normal saline (control group) intraperitoneally every $8 \mathrm{~h}$, starting at $32 \mathrm{~h}$ following the onset of hyperoxic exposure. The mice were then inoculated with PA as described previously (Patel et al. 2013). Bacterial load, both in the airways and lung tissue, was significantly 
decreased in a dose-dependent manner in animals treated with GTS-21 compared to controls (Fig. 1). GTS21 , at $4 \mathrm{mg} / \mathrm{kg}$, significantly decreased bacterial counts in the lungs $(4.85 \pm 0.48 \mathrm{log} C F U s /$ lung vs controls $6.39 \pm 0.34 \log$ CFUs/lung, $\mathrm{p}<0.05$; Fig. 1a) and in the airways $(4.66 \pm 0.45 \mathrm{log} \mathrm{CFUs} / \mathrm{ml}$ vs controls $5.94 \pm 0.26$ $\log$ CFUs/ml of BAL, $\mathrm{p}<0.05$; Fig. 1b). Mice that received $4 \mathrm{mg} / \mathrm{kg}$ i.p. of GTS-21 also had significantly lower total protein content in the lung lavage samples (a marker of lung injury) compared to mice given normal saline $(2755.34 \pm 827.78$ vs. $5204.70 \pm 553.03 \mu \mathrm{g} / \mathrm{ml}, \mathrm{p}<0.05$; Fig. 1c). These data suggest that GTS-21 is efficacious in increasing bacterial clearance and decreasing acute lung injury in the mouse model of VAP.

\section{GTS-21 restores hyperoxia-compromised phagocytic activity of macrophages in hyperoxia}

Previous studies in our lab indicate that hyperoxic exposure can compromise macrophage phagocytic activity and decrease the clearance of pathogenic bacteria (Patel et al. 2013; Entezari et al. 2012). Therefore, we determined if GTS-21-improved bacterial clearance in the mouse model of VAP results from an increase in the phagocytosis of microorganisms by hyperoxic macrophages. As previously reported (Morrow et al. 2007; Patel et al. 2013), the phagocytotic activity of hyperoxia-exposed macrophages was significantly decreased compared to macrophages cultured in room air, $21 \% \mathrm{O}_{2}(42.8 \pm 1.9 \%$ versus $100.05 \pm 2.06, \mathrm{p}<0.001$; Fig. 2). In vitro, GTS-21, at 5,25 and $50 \mu \mathrm{M}$, significantly increased the phagocytic activity of macrophages to $70.3 \pm 5.8,84.5 \pm 7.3$ and $80.1 \pm 11.6 \%$ respectively, from that of macrophages exposed to $95 \% \mathrm{O}_{2}$ alone $(42.8 \pm 1.9 \%, \mathrm{p}<0.05)$. These data suggest that GTS-21 can increase hyperoxic macrophage phagocytosis.

\section{GTS-21 inhibits the accumulation of extracellular HMGB1 induced by hyperoxic exposure}

The exposure of macrophages to hyperoxia induces the release of nuclear HMGB1 into the extracellular milieu, which decreases the phagocytic activity of AMs (Liu et al. 2008; Entezari et al. 2012). To determine if
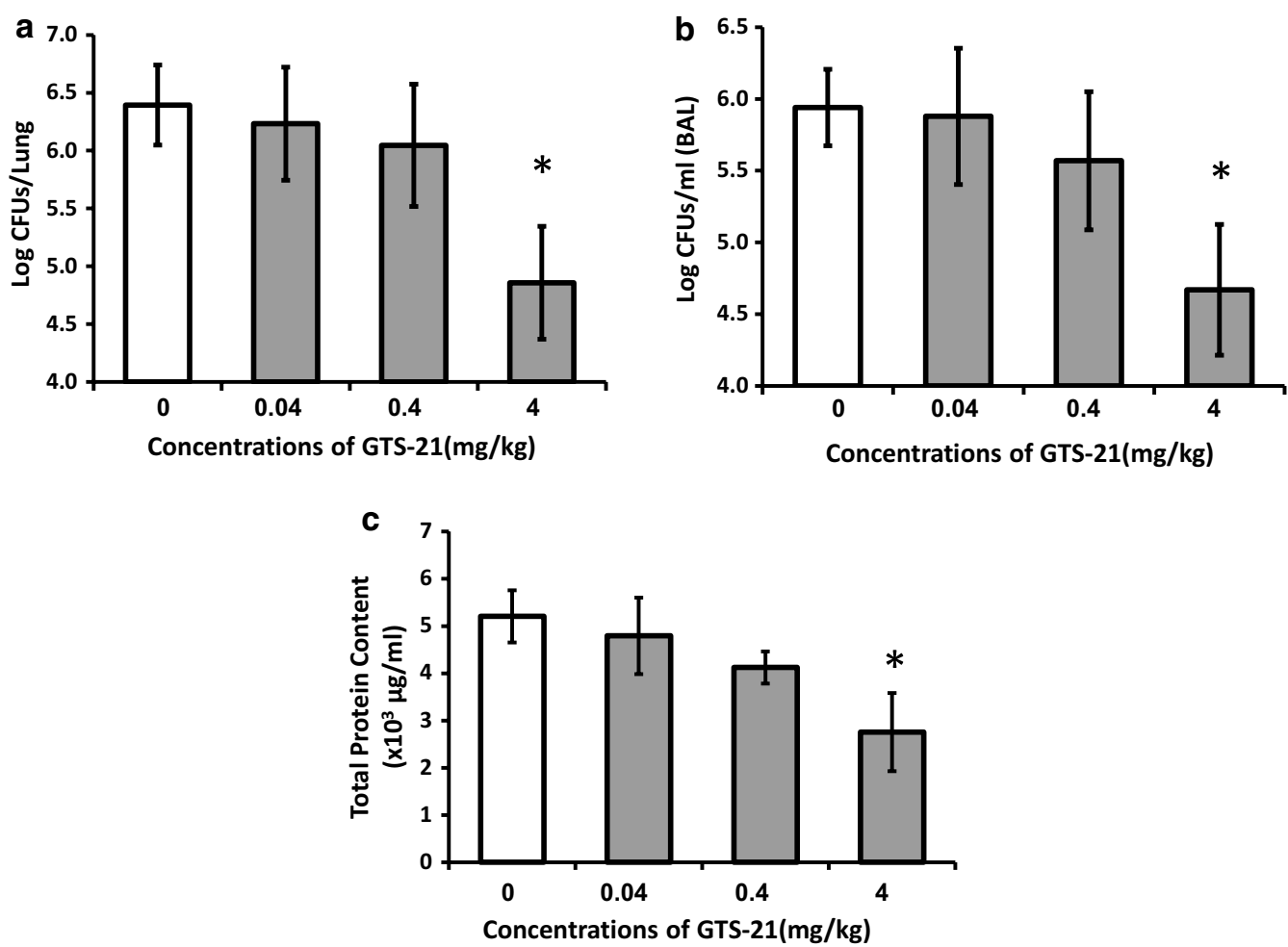

Fig. 1 Systemic administration of GTS-21 increases bacterial clearance and decreases acute lung injury in mice exposed to hyperoxia and challenged with PA. C57BL/6 mice were exposed to $\geq 99 \% \mathrm{O}_{2}$ for $48 \mathrm{~h}$ and then inoculated with PA $\left(0.1 \times 10^{8} \mathrm{CFUs} / \mathrm{mouse}\right)$, and returned to $21 \%$ $\mathrm{O}_{2}$ after inoculation. Mice were randomized to receive either GTS-21 $(0.04,0.4$, and $4 \mathrm{mg} / \mathrm{kg})$ or saline, administrated by intraperitoneal injection, every $8 \mathrm{~h}$ starting at $32 \mathrm{~h}$ during hyperoxia. BAL and lung tissue were harvested $18 \mathrm{~h}$ after inoculation. Viable bacteria in the airways and lungs were quantified by plating serial dilutions of homogenized lung (a) and BAL (b), and are expressed as log CFUs/lung and log CFUs/ml of BAL, respectively. The total protein content in the BAL (c) was measured as a marker of lung injury. Data represent the means \pm SEMs from two independent experiments ( $n=5$ for control, $n=6$ for all GTS-21 treated mice). ${ }^{*} p<0.05$, compared with mice receiving normal saline 

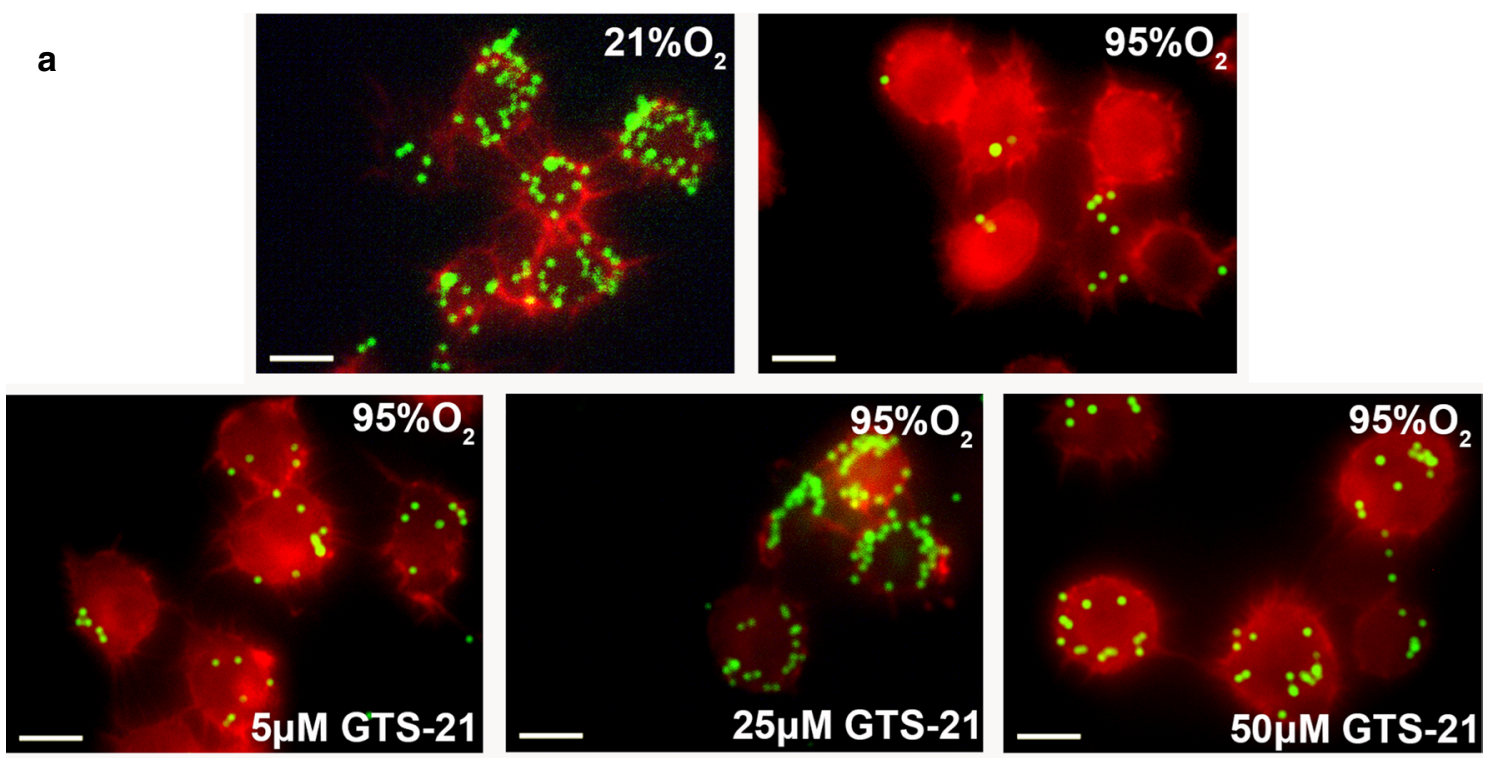

b

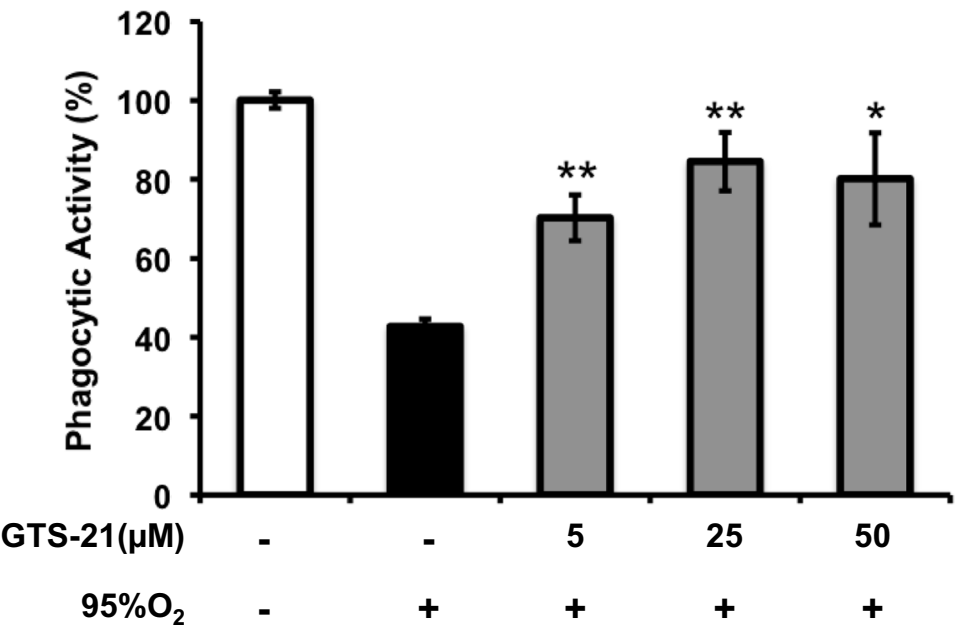

Fig. 2 GTS-21 restores hyperoxia-compromised phagocytic activity of macrophages. RAW 264.7 cells were either exposed to $95 \% \mathrm{O}_{2}$ alone (black bar) or $95 \% \mathrm{O}_{2}$ in the presence of different concentrations of GTS-21 (grey bars) or remained at $21 \% \mathrm{O}_{2}$ (white bar) for 24 h. Cells were then incubated with FITC-labeled latex minibeads for $1 \mathrm{~h}$ and stained with phalloidin to visualize the cells. a Immunofluorescent images of RAW 264.7 cells (Red: actin cytoskeleton; Green: minibeads). At least 250 cells per well from 3 independent experiments were counted and the number of beads per cell was represented as percent beads phagocytosed in the bar graph (b). Each value represents mean $\pm S E M$ of three independent experiments for each group. ${ }^{*} p<0.05$ and ${ }^{* *} p<0.01$ versus $95 \% \mathrm{O}_{2}$ alone (black bar). Bar, $10 \mu \mathrm{m}$

the GTS-21-induced increase in host defense and macrophage function is due to a decreased accumulation of extracellular HMGB1, RAW 264.7 cells were exposed to either $95 \% \mathrm{O}_{2}$ alone or $95 \% \mathrm{O}_{2}$ in the presence of GTS-21 $(5,25$ and $50 \mu \mathrm{M})$. Consistent with our previous results (Patel et al. 2013; Entezari et al. 2014), the exposure of RAW 264.7 cells to $95 \% \mathrm{O}_{2}$ for $24 \mathrm{~h}$ induced a significant release of nuclear HMGB1 into the extracellular milieu (Fig. 3a). GTS-21, at 25 and $50 \mu \mathrm{M}$, significantly inhibited hyperoxia-induced HMGB1 release $(61.76 \pm 6.57$ and $42.22 \pm 11.24$ respectively versus $97.43 \pm 1.45, \mathrm{p}<0.01$; Fig. 3a).

Recent studies in our lab indicated that hyperoxiasuppressed bacterial clearance in PA pneumonia is associated with a substantial accumulation of extracellular HMGB1 in the airways (Patel et al. 2013). To determine if the levels of extracellular HMGB1 in the airways of hyperoxic animals are altered in GTS-21-treated mice, 


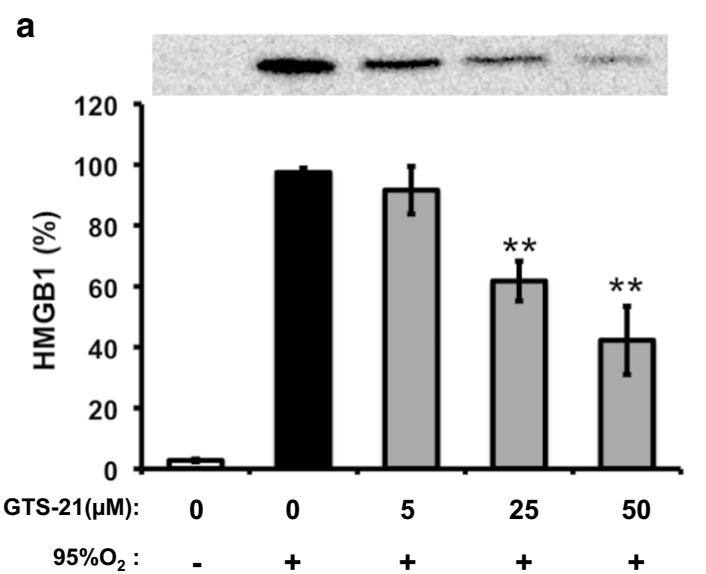

b

HMGB1
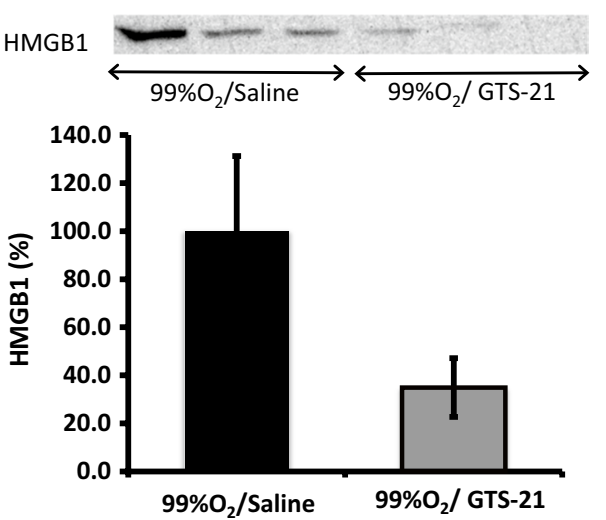

Fig. 3 GTS-21 inhibits the accumulation of extracellular HMGB1. a RAW 264.7 cells were either exposed to $95 \% \mathrm{O}_{2}$ alone (black bar) or $95 \% \mathrm{O}_{2}$ in the presence of a series of concentrations of GTS-21 (grey bars) or remained at 21\% $\mathrm{O}_{2}$ (white bar) for $24 \mathrm{~h}$. HMGB1 levels in cell culture media were analyzed by Western blot analysis. Representative image of the immunoreactive bands on Western blots is shown. Bar graph shows the integrated density value of HMGB1 bands. The data are expressed as mean \pm SEM of three independent experiments. ${ }^{* *} p<0.01$ versus control $95 \% \mathrm{O}_{2}$ alone (black bar). $\mathbf{b}$ C57BL/6 mice were exposed to $\geq 99 \% \mathrm{O}_{2}$ for $48 \mathrm{~h}$ and then inoculated with PA $\left(0.1 \times 10^{8} \mathrm{CFUs} / \mathrm{mouse}\right)$, and returned to $21 \% \mathrm{O}_{2}$ after inoculation. Mice were randomized to receive either GTS-21 or saline, administrated by intraperitoneal injection every $8 \mathrm{~h}$, starting at $32 \mathrm{~h}$ during hyperoxia. Representative image of Western blot immunoreactive bands of HMGB1 in the BAL of these mice is shown. Bar graph shows the integrated density value of HMGB1 bands in BAL of mice that received saline (black bar, $\mathrm{n}=5)$ and GTS-21 (4 mg/kg, grey bar, $n=6)$

we measured the concentrations of airway HMGB1 in lung lavage fluids from mice exposed to hyperoxia and treated with GTS-21. Figure 3b shows that mice treated with $4 \mathrm{mg} / \mathrm{kg}$ i.p. of GTS-21 had a decrease in the accumulation of extracellular HMGB1 in the airways, compared to mice treated with normal saline $(34.9 \pm 12.23$ versus $100.0 \pm 31.24, \mathrm{p}=0.106, \mathrm{n}=5$ for saline, and $\mathrm{n}=6$ for GTS-21 treated mice). These data suggest that GTS21 is efficacious in decreasing the accumulation of high levels of HMGB1 in the airways of hyperoxic animals by decreasing the release of nuclear HMGB1 from lung cells induced by prolonged exposure to hyperoxia.

\section{GTS-21 inhibits hyperoxia-induced HMGB1 release by blocking HMGB1 translocation from the nucleus to the cytoplasm}

Prior to its release, HMGB1 translocates from the nucleus to the cytoplasm, a critical step in its extracellular secretion (Bonaldi 2003; Scaffidi et al. 2002). To test whether GTS-21 can inhibit HMGB1 translocation in hyperoxic macrophages, HMGB1 was visualized using immunofluorescence in RAW 264.7 cells that were exposed to either $95 \% \mathrm{O}_{2}$ alone or $95 \% \mathrm{O}_{2}$ in the presence of GTS21. Exposure to hyperoxia induced the translocation of HMGB1 from the nucleus to the cytoplasm as indicated by a significant decrease in the amount HMGB1 localized within the nucleus $(0.109 \pm 0.03$ Mander's correlation coefficient, $\mathrm{p}<0.01)$ compared to macrophages that remained in room air conditions $(0.292 \pm 0.02$ Mander's correlation coefficient; Fig. 4). In contrast, cells incubated with GTS-21 $(50 \mu \mathrm{M})$ had a significant increase in the amount of HMGB1 located in the nucleus $(0.277 \pm 0.02$ Mander's correlation coefficient, $\mathrm{p}<0.01$; Fig. 4) when compared the hyperoxia and vehicle treated cells. The increased levels of HMGB1 in the nuclei of macrophages incubated with GTS-21 were similar to that of the room air control group. This data indicates that GTS-21 is efficacious in inhibiting hyperoxia-induced translocation of HMGB1.

\section{GTS-21 inhibits hyperoxia-induced NF-KB activation}

To determine the underlying mechanism of the GTS21-mediated decrease of HMGB1 nucleocytoplasmic translocation, we assessed the localization of NF-kB p65 subunit, a marker for NF- $\mathrm{kB}$ activation status (Franek et al. 2002). The p65 subunit of NF-kB was primarily localized in the cytoplasm of RAW cells exposed to room air $(0.203 \pm 0.023$ Mander's correlation coefficient of nuclear NF-kB p65 subunit) (Fig. $5 \mathrm{a}, \mathrm{b}, 21 \% \mathrm{O}_{2}$ ). In contrast, there was an $85.9 \%$ increase in the presence of the NF- $\mathrm{kB}$ p65 subunit in the nuclei (which is indicative of NF- $\mathrm{kB}$ activation) in RAW cells exposed to hyperoxia $(0.378 \pm 0.006$ Mander's correlation coefficient) (Fig. 5a, b, 95\% $\mathrm{O}_{2}$ ). When compared to control macrophages exposed to hyperoxia alone, macrophages incubated with GTS-21 $(50 \mu \mathrm{M})$ had a significant decreased in nuclear NF-кB p65 $(0.211 \pm 0.0608$ Mander's correlation coefficient, $\mathrm{p}<0.05$, Fig. $5 \mathrm{a}, \mathrm{b})$, which was not significantly 

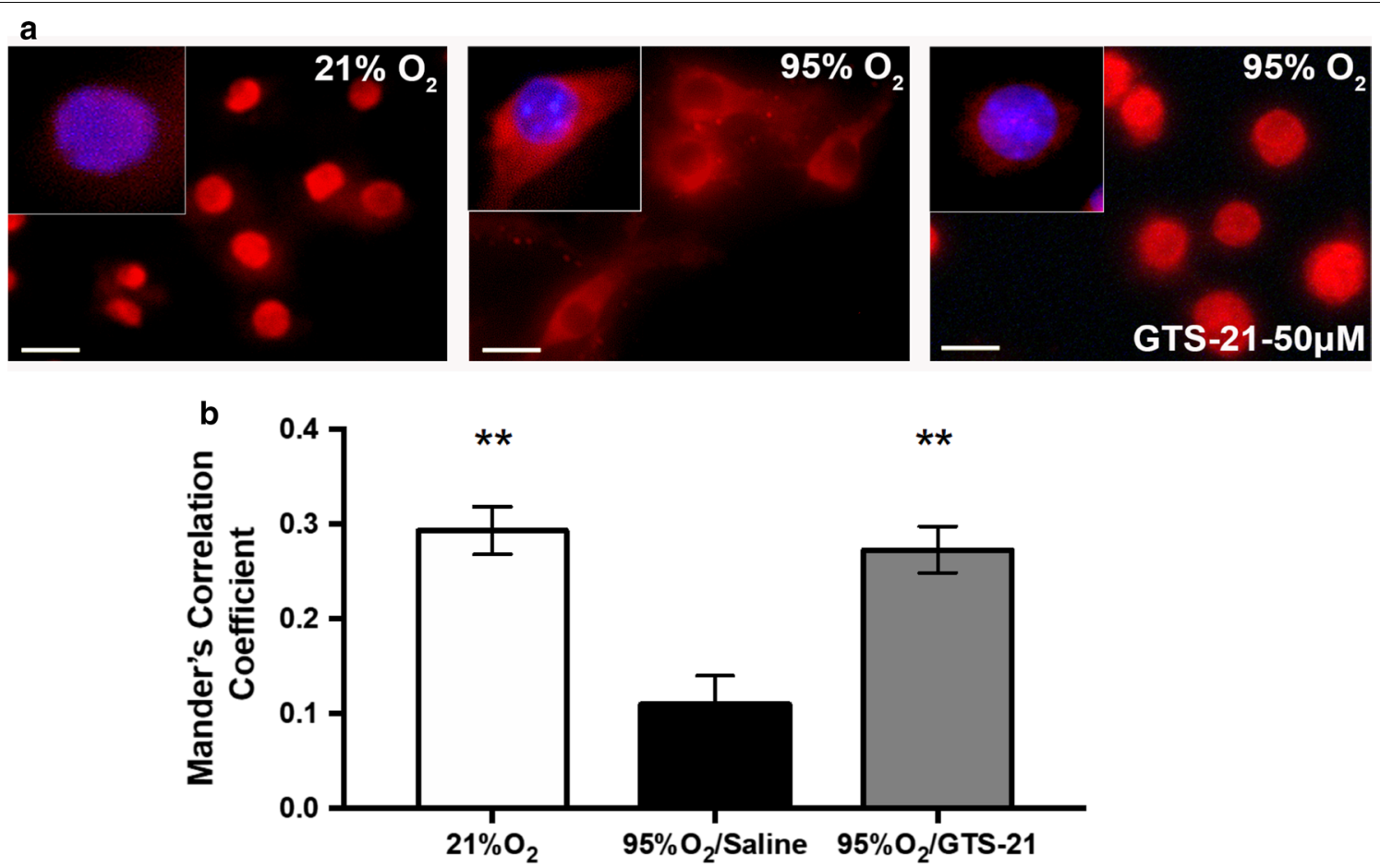

Fig. 4 GTS-21 inhibits cytoplasmic translocation of nuclear HMGB1 in macrophages. a RAW 264.7 cells were either exposed to $21 \% \mathrm{O}_{2}$ or $95 \% \mathrm{O}_{2}$ in the absence or presence of GTS-21 (50 $\mu \mathrm{M})$ for $24 \mathrm{~h}$. HMGB1 localization was visualized by immunofluorescence microscopy with anti-HMGB1 antibody (Red). Counterstaining with DAPI was used to visualize nuclei (Blue). Bar, $10 \mu \mathrm{m}$. Multiple pictures were taken using immunofluorescence microscope to visualize HMGB1. b Immunofluorescent micrographs were quantified by determining the amounts of HMGB1 colocalized into the nucleus using a Mander's correlation coefficient. The immunofluorescence images shown are representative of three independent experiments

different from cells exposed to room air of a $4.09 \%$ increase in NF- $\mathrm{KB}$ p 65 activation relative to room air control cells. Similarly, a decrease in the levels of nuclear NF-kB p65 subunit was seen in lung cells of mice treated with $4 \mathrm{mg} / \mathrm{kg}$ i.p. of GTS-21 (Fig. 5c). In addition, elevated levels of IкB, an inhibitor of NF-kB activation, were found in lung cytoplasmic extracts of mice treated with $4 \mathrm{mg} / \mathrm{kg}$ i.p. of GTS-21, compared to mice that received saline (Fig. 5c). These results suggest that GTS-21 is efficacious in blocking hyperoxia-induced NF- $\mathrm{kB}$ activation.

\section{Discussion}

We have previously shown that high levels of extracellular HMGB1, released from the nuclei of hyperoxia-exposed lung cells, compromise macrophage phagocytosis and bacterial clearance in a mouse model of VAP (Patel et al. 2013). In this study, our results indicated that GTS-21, an $\alpha 7 \mathrm{nAChR}$ agonist, inhibits hyperoxia-induced accumulation of HMGB1 in the airways of mice in a model of VAP, by attenuating the release of nuclear HMGB1. The inhibition of HMGB1 release was due to a decrease in the translocation of HMGB1 from the nucleus to the cytoplasm. The decrease in HMGB1 translocation was associated with an attenuation of the activation of
NF- $\mathrm{B}$. Importantly, the intraperitoneal administration of GTS-21 dose-dependently increased bacterial clearance from the airways and the lungs and decreased acute lung injury in the mouse model of VAP. Furthermore, hyperoxia-compromised macrophage phagocytosis was restored in cells incubated with GTS-21. These results suggest that GTS-21 increases bacterial clearance by improving hyperoxia-compromised phagocytic function of macrophages by inhibiting HMGB1 translocation and release.

Extracellular HMGB1, released from either the nuclei of intact immune cells or necrotic cells, has been implicated in the pathophysiology of a number of diseases (Scaffidi et al. 2002; Yang et al. 2001). For example, HMGB1 has been postulated to play a role in the pathogenesis of inflammatory diseases such as sepsis and rheumatoid arthritis (Wang 1999; Andersson et al. 2000; Yang et al. 2004; Taniguchi et al. 2003). In addition, extracellular HMGB1 impairs macrophage phagocytosis (Liu et al. 2008; Entezari et al. 2012) and host defense against bacterial infection in mouse models of VAP and CF (Patel et al. 2013; Entezari et al. 2012). Therefore, inhibiting the accumulation of extracellular HMGB1 may significantly attenuate the adverse effects of extracellular HMGB1 


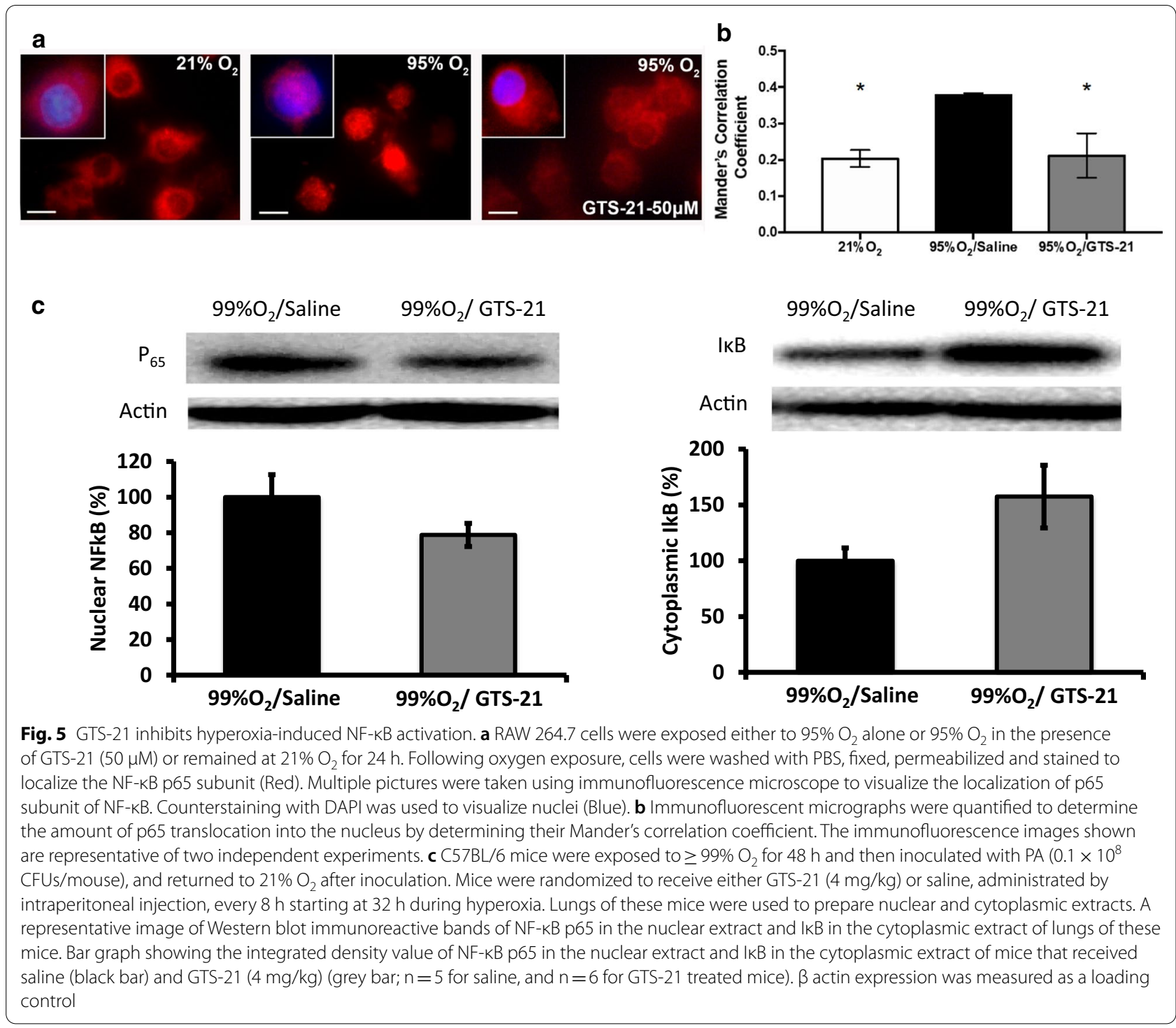

in excessive inflammatory responses and compromised innate immunity. In this study, GTS-21 significantly increased bacterial clearance from the lungs of mice exposed to hyperoxia and challenged with PA (Fig. 1). The improved lung function in GTS-21 treated animals with bacterial infection is correlated with a decrease in HMGB1 accumulation in the airways (Fig. 3). Similarly, GTS-21 can inhibit HMGB1 release from immune cells incubated with the inflammatory molecule, LPS (Pavlov et al. 2007; Rosas-Ballina et al. 2009) and decrease serum HMGB1 levels in a mouse model of endotoxemia (Pavlov et al. 2007). In addition, in LPS-stimulated mice, GTS-21 treatment significantly decreased the levels of HMGB1 in the airway and serum (Wang et al. 2019). Nicotine, a non-selective $\alpha 7 \mathrm{nAChR}$ agonist, inhibits HMGB1 release from LPS-stimulated macrophages and increases the survival of animals in a cecal ligation and puncture (CLP) model of sepsis (Wang et al. 2004). Recently, our lab has reported that in mice exposed to $72 \mathrm{~h}$ of hyperoxia, $4 \mathrm{mg} /$ kg i.p. administration of GTS-21 significantly attenuates the accumulation of HMGB1 in the airways and the circulation and mitigates inflammatory lung injury by decreasing the infiltration of neutrophils and inflammatory monocytes into the lung and the airways (Sitapara et al. 2020). Thus, these data suggest that the activation of the $\alpha 7 \mathrm{nAChR}$ with agonists, such as GTS-21 or nicotine, may represent a pharmacological approach to combat Gram-negative bacterial infections in organisms subjected to oxidative stress (Entezari et al. 2012; Wang 1999; Ogawa et al. 2006; Rowe et al. 2008). 
A critical step in the release of nuclear HMGB1 is its translocation from the nucleus into the cytoplasmic endolysosomes ( $\mathrm{Li}$ et al. 2003; Rendon-Mitchell et al. 2003). Under normoxic conditions, HMGB1 regularly shuttles between the nucleus and the cytoplasm, but primarily resides in the nucleus (Bonaldi 2003). Here, our results indicated that hyperoxia induces translocation of nuclear HMGB1 into the cytoplasm, which produces accumulation of extracellular HMGB1 in cultured media (Figs. 3, 4).

It is possible that GTS-21 suppresses HMGB1 release through a mechanism that resembles vagus nerve stimulation (Wang et al. 2003). Vagus nerve stimulation releases acetylcholine, which acts on the $\alpha 7 \mathrm{nAChR}$, to inhibit NF- $\kappa B$ signaling and prevent TNF- $\alpha$ production during endotoxemia (Ando 1997; Guarini et al. 2003).

\section{ROOM AIR}

HYPEROXIA

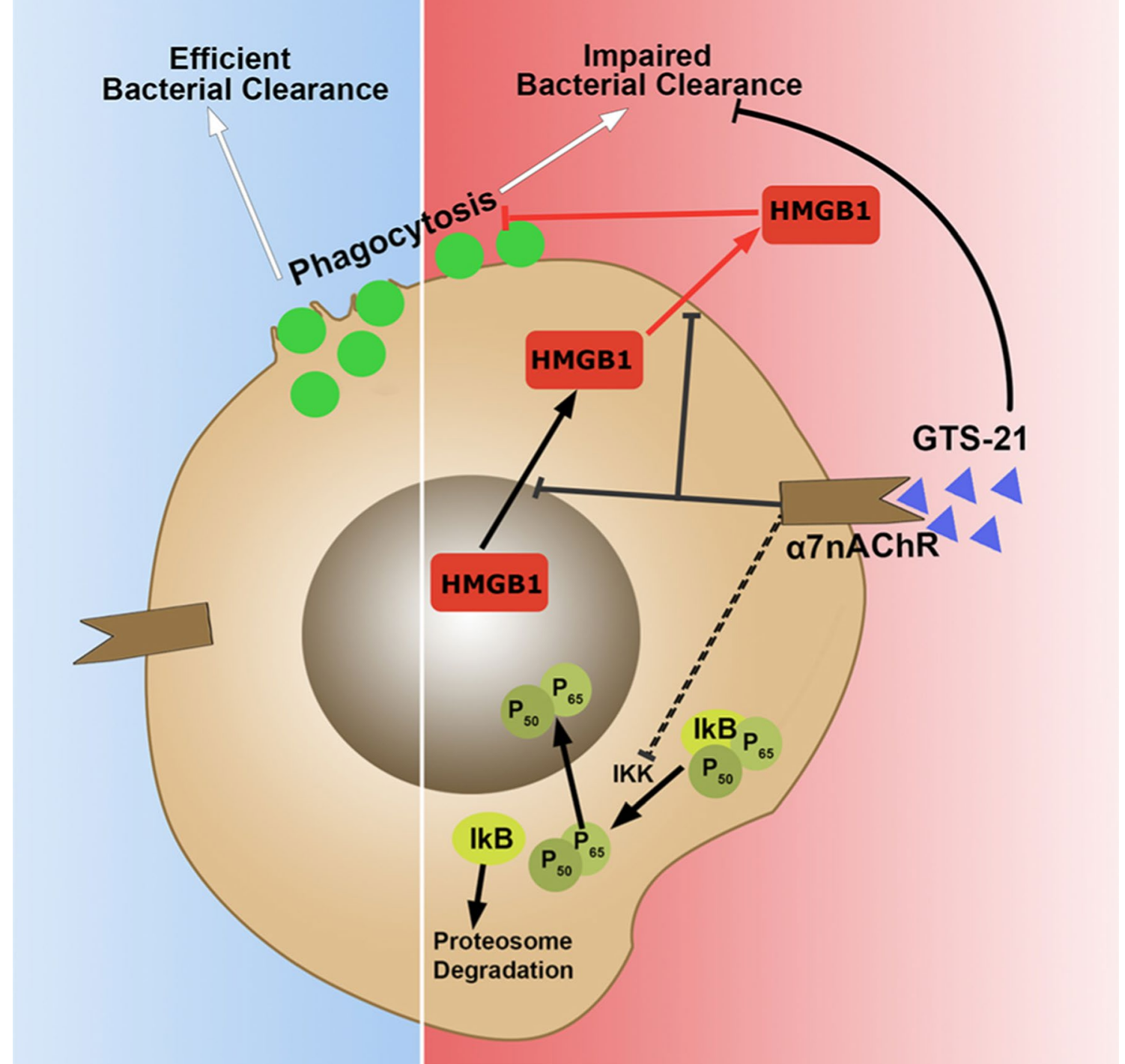

Fig. 6 Hypothesized pathway of GTS-21 inhibited hyperoxia-induced HMGB1 release and improved hyperoxia-compromised macrophage function in bacterial clearance. Under room air conditions, alveolar macrophages (AMs) maintain normal phagocytic activity and efficiently clear bacteria. When macrophages are exposed to hyperoxia, NF-KB p65 subunit is translocated into the nucleus, whereas HMGB1 translocates from the nucleus into the cytoplasm and subsequently into the extracellular milieu, decreasing phagocytosis and bacterial clearance by macrophages. GTS- 21 significantly attenuates hyperoxia-impaired bacterial clearance by binding to a7nAChR and suppressing HMGB1 translocation into the cytoplasm and release, which subsequently decreases the accumulation of extracellular HMGB1. GTS-21 also inhibits NF-kB p65 subunit translocation into the nucleus, which may prevent HMGB1 translocation and subsequent release into the extracellular milieu 
As part of the cholinergic anti-inflammatory pathway, the activation of $\alpha 7 \mathrm{nAChR}$ may play a beneficial role in attenuating acute lung injury by decreasing the HMGB1induced inflammatory response (Andersson 2020). Both nicotine (a non-selective $\alpha 7 \mathrm{nAChR}$ agonist) and GTS21 inhibit endotoxin-induced NF- $\mathrm{kB}$ activation in macrophages (Wang et al. 2003; Pavlov et al. 2007). We have reported that NF- $\mathrm{kB}$ activation plays a critical role in hyperoxia-induced HMGB1 release (Wang et al. 2015) and GTS-21 significantly decreases HMGB1 accumulation in the airways and the circulation in mice subjected to hyperoxia (Sitapara et al. 2020). Hyperoxia-induced $\mathrm{NF}-\mathrm{KB}$ activation in cultured macrophages and mouse lung cells is inhibited by GTS-21, suggesting the possible involvement of NF- $\mathrm{kB}$ in mediating GTS-21's decrease of hyperoxia-induced HMGB1 release (Fig. 6). Overall, our results suggest GTS-21 attenuates the release and accumulation of extracellular HMGB1 by attenuating oxidative stress/infection-induced activation of NF- $\mathrm{KB}$ and its down-stream pre-inflammatory responses.

To our knowledge, this study is the first to report that GTS-21 increases macrophage phagocytic function which is essential in combating pulmonary bacterial infections. In this study, GTS-21 significantly increased the phagocytic activity of hyperoxic macrophages (Fig. 2) and increased bacterial clearance from hyperoxiaexposed mice with PA pneumonia (Fig. 1). The restoration of macrophage phagocytosis by GTS-21 occurred at concentrations of $5-50 \mu \mathrm{M}$ and is, in part, due to the inhibition of HMGB1 release. In addition, extracellular HMGB1 impairs macrophage clearance of apoptotic neutrophils, which may exacerbate bacterial infections by producing inflammatory tissue injury (Liu et al. 2008; Patel et al. 2013). Thus, our results suggest that GTS21 restores the phagocytic function of macrophages by inhibiting the extracellular accumulation of HMGB1 by attenuating NF-kB activation (Fig. 6). Furthermore, GTS21 significantly attenuates the levels of pro-inflammatory cytokines, such as TNF- $\alpha$, and increases the survival of animals subjected to polymicrobial infections (Pavlov et al. 2007). Overall, targeting pathways to attenuate the accumulation of extracellular HMGB1 by GTS-21 may be a novel approach to develop therapies to treat bacterial infections in patients with VAP.

\section{Conclusions}

In summary, our results indicate that the $\alpha 7 \mathrm{nAChR}$ agonist, GTS-21, significantly decreases hyperoxia-induced HMGB1 release from hyperoxic macrophages and lung cells, most likely by inhibiting its translocation into the cytoplasm from nuclei. Importantly, GTS-21 significantly increased bacterial clearance in a mouse model of VAP, most likely by increasing the phagocytotic activity of macrophages due to hyperoxia-suppressed. These results suggest that $\alpha 7 \mathrm{nAChR}$ may represent a pharmacological target for improving the clinical outcome in patients receiving non-invasive and invasive oxygen therapy by augmenting host defense against bacterial infections. These results may also provide mechanistic insight and an avenue for potential treatment strategies in alleviating the pro-inflammatory syndrome and pneumonia commonly found in severe COVID-19 patients.

\section{Abbreviations \\ a7nAChR: Alpha 7 nicotinic acetylcholine receptor; BAL: Bronchoalveolar lavage; GTS-21: 3-(2,4 Dimethoxy-benzylidene)-anabaseine dihydrochloride; HMGB1: High mobility group box protein 1; Hyperoxia: Greater than 99\% or 95\% oxygen; MV: Mechanical ventilation; VAP:Ventilator-associated pneumo- nia; AM: Alveolar macrophages; LPS: Lipopolysaccharide; PA: Pseudomonas aeruginosa; RA: Room air (21\% oxygen); NF-kB: Nuclear factor kappa-light- chain-enhancer of activated B cells; IkB: Inhibitor of NF-kB; TNF: Tumor necrosis factor}

\section{Acknowledgements}

This study was funded by grants from The National Heart and Blood Institute (HL093708, to LLM) and intramural grants from St. John's University (to LLM). We would also like to thank Dr. Huan Yang for her insightful discussion on this project.

\section{Authors' contributions}

RS, LLM, AG, ML, and VP designed and performed experiments. RS, AG, VP, ML, CRA and LLM analyzed data. RS, AG, VP, ML, MZ, CRA, and LLM conceived the project and wrote the paper. All authors read and approved the final manuscript.

\section{Availability of data and materials}

The datasets used and/or analyzed during the current study are available from the corresponding author on reasonable request.

Ethics approval and consent

The study was reviewed and approved by the IACUC at St. John's University.

Consent for publications

All authors read and approved the manuscript.

Competing interests

The authors have no competing interests to declare.

\section{Author details}

${ }^{1}$ Department of Pharmaceutical Sciences, St. John's University College of Pharmacy and Health Sciences, 8000 Utopia Parkway, Queens, NY 11439, USA. ${ }^{2}$ The Feinstein Institute for Medical Research, Northwell Health System, Manhasset, NY 11030, USA.

Received: 30 August 2020 Accepted: 7 October 2020

Published online: 30 October 2020

\footnotetext{
References

Aberdein J, Cole J, Bewley M, Marriott HM, Dockrell DH. Alveolar macrophages in pulmonary host defence-the unrecognised role of apoptosis as a mechanism of intracellular bacterial killing. Clin Exp Immunol. 2013;174:193-202.

Andersson $U$. The cholinergic anti-inflammatory pathway alleviates acute lung injury. Mol Med. 2020;26:64.

Andersson U, Tracey KJ. HMGB1 Is a therapeutic target for sterile inflammation and infection. Annu Rev Immunol. 2011;29:139-62.
} 
Andersson U, Wang H, Palmblad K, Aveberger A-C, Bloom O, Erlandsson-Harris $H$, Janson A, Kokkola R, Zhang M, Yang H, Tracey KJ. High mobility group 1 protein ( $\mathrm{Hmg}-1$ ) stimulates proinflammatory cytokine synthesis in human monocytes. J Exp Med. 2000;192:565-70.

Ando Y. Transdermal nicotine for ulcerative colitis. Ann Intern Med. 1997;127:491.

Baleeiro CEO, Wilcoxen SE, Morris SB, Standiford TJ, Paine R. Sublethal hyperoxia impairs pulmonary innate immunity. J Immunol. 2003;171:955-63.

Bonaldi T. Monocytic cells hyperacetylate chromatin protein HMGB1 to redirect it towards secretion. EMBO J. 2003;22:5551-60.

Crowell RE, Hallin G, Heaphy E, Mold C. Hyperoxic suppression of Fc-gamma receptor-mediated phagocytosis by isolated murine pulmonary macrophages. Am J Respir Cell Mol Biol. 1995;12:190-5.

Davis KA. Ventilator-associated pneumonia: a review. J Intensive Care Med. 2006:21:211-26.

Entezari M, Weiss DJ, Sitapara R, Whittaker L, Wargo MJ, Li J, Wang H, Yang H, Sharma L, Phan BD, Javdan M, Chavan SS, Miller EJ, Tracey KJ, Mantell LL. Inhibition of high-mobility group box 1 protein (HMGB1) enhances bacterial clearance and protects against Pseudomonas aeruginosa pneumonia in cystic fibrosis. Mol Med. 2012;18:477-85.

Entezari M, Javdan M, Antoine DJ, Morrow DMP, Sitapara RA, Patel V, Wang M, Sharma L, Gorasiya S, Zur M, Wu W, Li J, Yang H, Ashby CR, Thomas D, Wang H, Mantell LL. Inhibition of extracellular HMGB1 attenuates hyperoxia-induced inflammatory acute lung injury. Redox Biol. 2014;2:314-22.

Franek WR, Chowdary YC, Lin X, Hu M, Miller EJ, Kazzaz JA, Razzano P, Romashko J, Davis JM, Narula P, Horowitz S, Scott W, Mantell LL. Suppression of nuclear factor-kB activity by nitric oxide and hyperoxia in oxygenresistant cells. J Biol Chem. 2002;277:42694-700.

Franke-Ullmann G, Pförtner C, Walter P, Steinmüller C, Lohmann-Matthes $\mathrm{ML}$, Kobzik L. Characterization of murine lung interstitial macrophages in comparison with alveolar macrophages in vitro. J Immunol. 1996;157:3097-104

Giebelen IAJ, van Westerloo DJ, LaRosa GJ, de Vos AF, van der Poll T. Local stimulation of a7 cholinergic receptors inhibits LPS-induced TNF-a release in the mouse lung. Shock. 2007;28:700-3.

Gore A, Gauthier AG, Lin M, Patel V, Thomas DD, Ashby CR, Mantell LL. The nitric oxide donor, (Z)-1-[N-(2-aminoethyl)-N-(2-ammonioethyl)amino] diazen-1-ium-1,2-diolate (DETA-NONOate/D-NO), increases survival by attenuating hyperoxia-compromised innate immunity in bacterial clearance in a mouse model of ventilator-associated pneumonia. Biochem Pharmacol. 2020;176:113817.

Guarini S, Altavilla D, Cainazzo M-M, Giuliani D, Bigiani A, Marini H, Squadrito G, Minutoli L, Bertolini A, Marini R, Adamo EB, Venuti FS, Squadrito F. Efferent vagal fibre stimulation blunts nuclear factor-kB activation and protects against hypovolemic hemorrhagic shock. Circulation. 2003;107:1189-94.

Kang R, Chen R, Zhang Q, Hou W, Wu S, Cao L, Huang J, Yu Y, Fan X, Yan Z, Sun X, Wang H, Wang Q, Tsung A, Billiar TR, Zeh HJ, Lotze MT, Tang D. HMGB1 in health and disease. Mol Aspects Med. 2014;40:1-116.

Khan MAS, Farkhondeh M, Crombie J, Jacobson L, Kaneki M, Martyn JAJ. Lipopolysaccharide up-regulates a7 acetylcholine receptors: stimulation with GTS-21 mitigates growth arrest of macrophages and improves survival in burned mice. Shock. 2012;38:213-9.

Li J, Kokkola R, Tabibzadeh S, Yang R, Ochani M, Qiang X, Harris HE, Czura CJ, Wang H, Ulloa L, Wang H, Warren HS, Moldawer LL, Fink MP, Andersson U, Tracey KJ, Yang H. Structural basis for the proinflammatory cytokine activity of high mobility group box 1. Mol Med. 2003;9:37-45.

Liu G, Wang J, Park Y-J, Tsuruta Y, Lorne EF, Zhao X, Abraham E. High mobility group protein-1 inhibits phagocytosis of apoptotic neutrophils through binding to phosphatidylserine. J Immunol. 2008;181:4240-6.

Morrow DMP, Entezari-Zaherab T, Romashko J, Azghani AO, Javdan M, Ulloa L, Miller EJ, Mantell LL. Antioxidants preserve macrophage phagocytosis of Pseudomonas aeruginosa during hyperoxia. Free Radical Biol Med. 2007:42:1338-49.

O'Reilly PJ, Hickman-Davis JM, Davis IC, Matalon S. Hyperoxia impairs antibacterial function of macrophages through effects on actin. Am J Respir Cell Mol Biol. 2003:28:443-50.

Ogawa EN, Ishizaka A, Tasaka S, Koh H, Ueno H, Amaya F, Ebina M, Yamada S, Funakoshi Y, Soejima J, Moriyama K, Kotani T, Hashimoto S, Morisaki H, Abraham E, Takeda J. Contribution of high-mobility group box-1 to the development of ventilator-induced lung injury. Am J Respir Crit Care Med. 2006;174:400-7.
Patel VS, Sitapara RA, Gore A, Phan B, Sharma L, Sampat V, Li JH, Yang H, Chavan SS, Wang H, Tracey KJ, Mantell LL. High mobility group box-1 mediates hyperoxia-induced impairment of Pseudomonas aeruginosa clearance and inflammatory lung injury in mice. Am J Respir Cell Mol Biol. 2013:48:280-7.

Patel VS, Sampat V, Espey MG, Sitapara R, Wang H, Yang X, Ashby CR, Thomas $\mathrm{DD}$, Mantell LL. Ascorbic acid attenuates hyperoxia-compromised host defense against pulmonary bacterial infection. Am J Respir Cell Mol Biol. 2016;55:511-20.

Patel V, Dial K, Wu J, Gauthier AG, Wu W, Lin M, Espey MG, Thomas DD, Ashby CR, Mantell LL. Dietary antioxidants significantly attenuate hyperoxiainduced acute inflammatory lung injury by enhancing macrophage function via reducing the accumulation of airway HMGB1. IJMS. 2020;21:977.

Pavlov VA, Ochani M, Yang L-H, Gallowitsch-Puerta M, Ochani K, Lin X, Levi J, Parrish WR, Rosas-Ballina M, Czura CJ, LaRosa GJ, Miller EJ, Tracey KJ, Al-Abed Y. Selective a7-nicotinic acetylcholine receptor agonist GTS-21 improves survival in murine endotoxemia and severe sepsis. Crit Care Med. 2007:35:1139-44.

Raffin TA, Simon LM, Braun D, Theodore J, Robin ED. Impairment of phagocytosis by moderate hyperoxia (40 to 60 per cent oxygen) in lung macrophages. Lab Invest. 1980;42:622-6.

Ramirez Barba EJ, Rosenthal VD, Higuera F, Oropeza MS, Hernández HT, López MS, Lona EL, Duarte P, Ruiz J, Hernandez RR, Chavez A, Cerrato IP, Ramirez GE, Safdar N. Device-associated nosocomial infection rates in intensive care units in four Mexican public hospitals. Am J Infect Control. 2006;34:244-7.

Rendon-Mitchell B, Ochani M, Li J, Han J, Wang H, Yang H, Susarla S, Czura C, Mitchell RA, Chen G, Sama AE, Tracey KJ, Wang H. IFN- $\gamma$ induces high mobility group box 1 protein release partly through a TNF-dependent mechanism. J Immunol. 2003;170:3890-7.

Richards MJ, Edwards JR, Culver DH, Gaynes RP. Nosocomial infections in medical intensive care units in the United States. National Nosocomial Infections Surveillance System. Crit Care Med. 1999:27:887-92.

Rister M. Effects of hyperoxia on phagocytosis. Blut. 1982;45:157-66.

Rosas-Ballina M, Goldstein RS, Gallowitsch-Puerta M, Yang L, Valdés-Ferrer SI, Patel NB, Chavan S, Al-Abed Y, Yang H, Tracey KJ. The selective a7 agonist GTS-21 attenuates cytokine production in human whole blood and human monocytes activated by ligands for TLR2, TLR3, TLR4, TLR9, and RAGE. Mol Med. 2009;15:195-202.

Rowe SM, Jackson PL, Liu G, Hardison M, Livraghi A, Solomon GM, McQuaid DB, Noerager BD, Gaggar A, Clancy JP, O'Neal W, Sorscher EJ, Abraham E, Blalock JE. Potential role of high-mobility group box 1 in cystic fibrosis airway disease. Am J Respir Crit Care Med. 2008;178:822-31.

Ruggiu M, Aissaoui N, Nael J, Haw-Berlemont C, Herrmann B, Augy J-L, Ortuno S, Vimpère D, Diehl J-L, Bailleul C, Guerot E. Hyperoxia effects on intensive care unit mortality: a retrospective pragmatic cohort study. Crit Care. 2018;22:218.

Scaffidi P, Misteli T, Bianchi ME. Release of chromatin protein HMGB1 by necrotic cells triggers inflammation. Nature. 2002;418:191-5.

Sitapara RA, Gauthier AG, Valdés-Ferrer SI, Lin M, Patel V, Wang M, Martino AT, Perron JC, Ashby CR, Tracey KJ, Pavlov VA, Mantell LL. The a7 nicotinic acetylcholine receptor agonist, GTS-21, attenuates hyperoxia-induced acute inflammatory lung injury by alleviating the accumulation of HMGB1 in the airways and the circulation. Mol Med. 2020;26:63.

Tablan OC, Anderson LJ, Besser R, Bridges C, Hajjeh R, CDC, Healthcare Infection Control Practices Advisory Committee. Guidelines for preventing health-care-associated pneumonia, 2003: recommendations of CDC and the Healthcare Infection Control Practices Advisory Committee. MMWR Recomm Rep. 2003;2004(53):1-36.

Taniguchi N, Kawahara K-I, Yone K, Hashiguchi T, Yamakuchi M, Goto M, Inoue K, Yamada S, ljiri K, Matsunaga S, Nakajima T, Komiya S, Maruyama I. High mobility group box chromosomal protein 1 plays a role in the pathogenesis of rheumatoid arthritis as a novel cytokine. Arthritis Rheum. 2003:48:971-81.

Ulloa L. The vagus nerve and the nicotinic anti-inflammatory pathway. Nat Rev Drug Discov. 2005;4:673-84.

van Zoelen MAD, Ishizaka A, Wolthuis EK, Choi G, van der Poll T, Schultz MJ. Pulmonary levels of high-mobility group box 1 during mechanical ventilation and ventilator-associated pneumonia. Shock. 2008;29:441-5.

Wang H. HMG-1 as a late mediator of endotoxin lethality in mice. Science. 1999:285:248-51. 
Wang H, Yu M, Ochani M, Amella CA, Tanovic M, Susarla S, Li JH, Wang H, Yang H, Ulloa L, Al-Abed Y, Czura CJ, Tracey KJ. Nicotinic acetylcholine receptor a7 subunit is an essential regulator of inflammation. Nature. 2003:421:384-8.

Wang $\mathrm{H}$, Liao H, Ochani M, Justiniani M, Lin X, Yang L, Al-Abed Y, Wang H, Metz C, Miller EJ, Tracey KJ, Ulloa L. Cholinergic agonists inhibit HMGB1 release and improve survival in experimental sepsis. Nat Med. 2004;10:1216-21.

Wang M, Gorasiya S, Antoine DJ, Sitapara RA, Wu W, Sharma L, Yang H, Ashby CR, Vasudevan D, Zur M, Thomas DD, Mantell LL. The compromise of macrophage functions by hyperoxia is attenuated by ethacrynic acid via inhibition of NF-kB-mediated release of high-mobility group box-1. Am J Respir Cell Mol Biol. 2015;52:171-82.

Wang M, Gauthier A, Daley L, Dial K, Wu J, Woo J, Lin M, Ashby C, Mantell LL. The role of HMGB1, a nuclear damage-associated molecular pattern molecule, in the pathogenesis of lung diseases. Antioxid Redox Signal. 2019a;31:954-93.
Wang J, Li R, Peng Z, Zhou W, Hu B, Rao X, Yang X, Li J. GTS-21 Reduces inflammation in acute lung injury by regulating $M 1$ polarization and function of alveolar macrophages. Shock. 2019b;51:389-400.

Yang H. The cytokine activity of HMGB1. J Leukoc Biol. 2005;78:1-8.

Yang H, Wang H, Tracey KJ. HMG-1 rediscovered as a cytokine. Shock. 2001;15:247-53.

Yang H, Ochani M, Li J, Qiang X, Tanovic M, Harris HE, Susarla SM, Ulloa L, Wang H, DiRaimo R, Czura CJ, Wang H, Roth J, Warren HS, Fink MP, Fenton MJ, Andersson U, Tracey KJ. Reversing established sepsis with antagonists of endogenous high-mobility group box 1. Proc Natl Acad Sci USA. 2004;101:296-301.

\section{Publisher's Note}

Springer Nature remains neutral with regard to jurisdictional claims in published maps and institutional affiliations.
Ready to submit your research? Choose BMC and benefit from:

- fast, convenient online submission

- thorough peer review by experienced researchers in your field

- rapid publication on acceptance

- support for research data, including large and complex data types

- gold Open Access which fosters wider collaboration and increased citations

- maximum visibility for your research: over 100M website views per year

At BMC, research is always in progress.

Learn more biomedcentral.com/submissions 